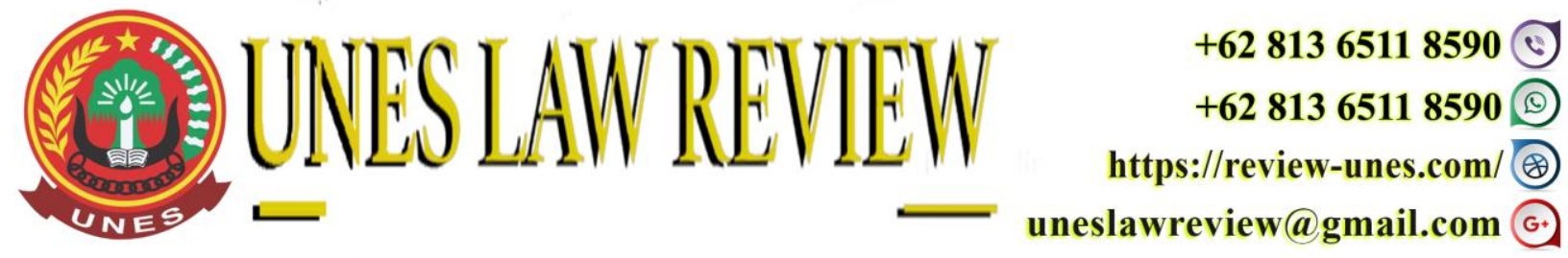

DOI: https://doi.org/10.31933/unesrev.v4i3

Diterima: 24/02/2022, Diperbaiki: 26/02/2022, Diterbitkan: 01/03/2022

\title{
IMPLIKASI PEMILIHAN KEPALA DAERAH SERENTAK SEBAGAI PERWUJUDAN DEMOKRASI PADA MASA PANDEMI COVID 19 DI KABUPATEN PESISIR SELATAN
}

\section{Aqri Febri Handra}

Program Magister Ilmu Hukum, Fakultas Hukum, Universitas Ekasakti, Padang, Indonesia.

Email: aqrifebrihandra@gmail.com

Corresponding Author: Aqri Febri Handra

\section{ABSTRACT}

Simultaneous Pilkada in 2020 should be used as the beginning for quality democracy. The COVID-19 pandemic has caused several changes in the implementation of regional elections, in accordance with KPU Decree Number: 179/PL.02-kpt/01/KPU/III/2020 concerning Postponing the Stages of Elections for Governors and Deputy Governors, Regents and Deputy Regents, and/or Mayor and Deputy Mayor in 2020 in Efforts to Prevent the Spread of Covid-19. These regulations, among others, regulate the postponement of the 2020 Pilkada stages in several parts, such as the inauguration and tenure of the Voting Committee (PPS), verification of the support requirements of individual candidates, the formation of a Voter Data Update Officer (PPDP) and the implementation of matching and research (coklit), as well as updating and preparation of voter lists. Analysis and discussion of the results obtained the following answers: (a) The implications of implementing simultaneous regional head elections as a manifestation of democracy during the Covid 19 pandemic in Pesisir Selatan Regency, namely increasing voter participation in the 2020 Pilkada compared to the 2015 Pilkada. The next implication is the emergence of disputes over the results of the vote in the election. (b) Obstacles in the implementation of simultaneous regional head elections as a manifestation of democracy during the Covid 19 pandemic in Pesisir Selatan Regency, namely the non-neutrality of the State Civil Apparatus in organizing the Pilkada by committing violations at several stages of the election, constraints on regional geographical conditions and obstacles in the equipment used to Pilkada.

Keywords: Implications, Regional Heads, Democracy, Covid-19 


\begin{abstract}
ABSTRAK
Pilkada Serentak Tahun 2020 seharusnya dadijadikan sebagai awal untuk demokrasi yang berkualitas. Pandemi COVID-19 menyebabkan beberapa perubahan dalam pelaksanaan pilkada, sesuai dengan Surat Keputusan KPU Nomor: 179/PL.02-kpt/01/KPU/III/2020 tentang Penundaan Tahapan Pemilihan Gubernur dan Wakil Gubernur, Bupati dan Wakil Bupati, dan/atau Wali Kota dan Wakil Wali Kota tahun 2020 dalam Upaya Pencegahan Penyebaran Covid-19. Peraturan ini diantaranya mengatur penundaan tahapan Pilkada 2020 pada beberapa bagian, seperti pelantikan dan masa kerja Panitia Pemungutan Suara (PPS), verifikasi syarat dukungan calon perseorangan, pembentukan Petugas Pemutakhiran Data Pemilih (PPDP) dan pelaksanaan pencocokan dan penelitian (coklit), serta pemutakhiran dan penyusunan daftar pemilih. Analisis dan pembahasan hasil didapat jawaban sebagai berikut: (a) Implikasi pelaksanaan pemilihan kepala daerah serentak sebagai perwujudan demokrasi pada masa pandemi Covid 19 di Kabupaten Pesisir Selatan, yaitu meningkatnya partisipasi pemilih pada Pilkada tahun 2020 dibanding Pilkada Tahun 2015. Implikasi selanjutnya adalah munculnya sengketa terhadap hasil perolehan suara dalam Pilkada. (b) Kendala dalam pelaksanaan pemilihan kepala daerah serentak sebagai perwujudan demokrasi pada masa pandemi Covid 19 di Kabupaten Pesisir Selatan yaitu tidak netralnya Aparatur Sipil Negara dalam penyelenggaran Pilkada dengan melakukan pelanggaran pada beberapa tahapan pilkada, kendala kondisi geografis daerah serta kendala dalam perangkat yang digunakan untuk Pilkada.
\end{abstract}

Kata Kunci: Implikasi, Kepala Daerah, Demokrasi, Covid-19

\title{
PENDAHULUAN
}

Indonesia adalah Negara Kesatuan yang berbentuk Republik dan terdiri dari adanya Pemerinta Pusat dam Pemerintah daerah, yaitu Provinsi, Kabupaten dan Kota. Undang-Undang Dasar Republik Indonesia tahun 1945 (UUD 1945) Pasal 18 ayat (4) menegaskan bahwa "Gubernur, Bupati, dan Walikota masing-masing sebagai kepala pemerintahan Provinsi, kabupaten, dan Kota dipilih secara demokratis".

Rumusan pasal 18 di atas menggambarkan beberapa hal, yaitu: ${ }^{1}$ a) Undang-undang Dasar Republik Indonesia tahun 1945tidak mengharuskan Kepala Daerah dipilih secara langsung, dan calon Kepala Daerah juga tidak harus berasal dari partai politik atau gabungan partai politik; b) frasa "dipilih secara demokratis" tidaklah dapat ditafsirkan bahwa rekrutmen pasangan calon menjadi kewenangan mutlak partai politik sebagai salah satu lembaga yang berfungsi melakukan rekrutmen politik dalam pengisian jabatan publik melalui mekanisme yang demokratis; c) rumusan Pasal 18 ayat (4) Undang-Undang Dasar Republik Indonesia tahun 1945 amandemen kedua 2000, dapat diartikan bahwa tata cara dan prosedur pemilu sesuai dengan Pasal amendemen ketiga 2001. Hal ini berarti pilkada langsung, dimana lembaga yang bertanggungjawab dalam pelaksanaannya adalah Komisi Pemilihan Umum dan berwenang melakukan rekrutman calon kepala daerah; d) Pasal 18 ayat (4) hanya mengharuskan yang dipilih secara demokratis adalah Kepala Daerah (Gubernur, Bupati, dan Walikota). Dengan kata lain Wakil Kepala Daerah (Wakil gubernur, Wakil Bupati, dan Wakil Walikota) tidak harus dipilih satu paket dengan Kepala Daerah.

\footnotetext{
${ }^{1}$ Suharizal, Pemilukada, Dinamika, dan Konsep Mendatang, Raja Grafindo Persada, Jakarta, 2011, hlm. 26.
} 
Pilkada merupakan ruang bagi developing democrary. Demokrasi dibangun sebagai penguatan masyarakat publik (political society), penguatan masyarakat ekonomi (economic society) dan penguatan masyarakat budaya (cultural society). Selanjutnya, demokrasi yang dibangun diantaranya penguatan dan engagement masyarakat sipil (voice, access and control), birokrasi yang netral, provisional dan usable, penguatan rule of law, serta institusionlasasi ekonomi dan politik. ${ }^{2}$

Situasi Indonesia yang dilanda pandemi Covid 19, membuat banyak perubahan yang cukup signifikan, sama seperti kondisi dunia umunya. Salah satu sektor yang terpengaruh adalah bidang politik. Berkaitan dengan bidang politik, salah satu aspek yang terpngaruh di Indonesia adalah demokrasi. Masalah demokrasi mengiringi permasalahan kesehatan, dimana persoalan ini merupakan tonggak utama bangsa. Sementara itu permasalahan ekonomi yang rapuh membuat kehidupan masyarakat menjadi sulit. Permasalahan politik tidak luput terkena dampak, terutama dengan pelaksanaan Pilkada serentan pada bulan Desember 2020. ${ }^{3}$

Pandemi Covid 19 membuat dilaksanakannya pilkada menjadi pilihan yang sulit. Kesulitan disebabkan pengambilan keputusan untuk melaksanakann Pilkada harus diambil secara bijak dan benar. Undang-undang Dasar Republik Indonesia tahun 1945telah memuat ketentuan tentang pemilihan umum secara khusus, khususnya tentang mekanisme pengambilan keputusan yang melibatkan rakyat secara luas dan langsung. Hal ini merupakan konsekuensi dari perubahan rumusan kedaulatan rakyat dalam ketentuan Pasal 1 ayat (2) Undang-Undang Dasar Republik Indonesia tahun 1945. Perubahan rumusan tentang kedaulatan menyebabkan, aliran mandat kedaulatan yang dimiliki rakyat dapat mengalir langsung secara periodik kepada lembagalembaga perwakilan rakyat dan kepala pemerintahan (presiden) melalui proses pemilihan yang langsung, umum bebas, dan rahasia.

Pada masa pandemic COVID-19 diperlukan norma yang mendukung pelaksanaan Pilkada. pasal Undang-undang 10 Tahun 2016 tentang Perubahan Kedua Atas Undang-Undang Nomor 1 Tahun 2015 Tentang Penetapan Peraturan Pemerintah Pengganti Undang-undang Nomor 1 Tahun 2014 Tentang Pemilihan Gubernur, Bupati, Dan Walikota dengan berbagai perubahannya dan Perpu No.2 Tahun 2020 tentang Undang-undang Nomor 1 Tahun 2015 tentang Penetapan Peraturan Pemerintah Pengganti Undang-undang Nomor 1 Tahun 2014 Tentang Pemilihan Gubernur, Bupati, dan Walikota Menjadi Undang-undang tidak serta merta menjadi lex specialis derogate legi generali atas regulasi kebijakan penanganan COVID-19 lainnya seperti diatur pada Perpu No.1 Tahun 2020 tentang Kebijakan Keuangan dan Stabilitas Sistem Keuangan untuk Penanganan Pandemi coronavirus disease 2019 (Covid-19) karena kondisi status kedaruratan bencana non alam sesuai dengan Keputusan Presiden RI No.12 Tahun 2020 tanggal 13 April 2020 tentang Penetapan Bencana Nonalam Penyebaran Corona Virus Disease 2019 (COVID-19) Sebagai Bencana Nasional yang juga merupakan kebijakan lex specialis derogate legi generali atas ketentuan perundangan lainnya. Karena itu kebijakan

\footnotetext{
${ }^{2}$ Gregorius Sahdan, "Pilkada dan Problem Demokrasi Lokal", dalam Gregorius Sahdan (et al), Politik Pilkada: Tantangan Merawat Demokrasi, The Indonesian Power for Democracy (IPD), Yogyakarta, 2008, hlm.155-157.

${ }^{3}$ Utomo, W. W.. Kebijakan Penyelenggaran Pilkada (Menghadapi Pilkada 2020 Ditengah Covid 19 Dan New Normal). Jurnal Al-Harakah, 3(01), 2020
} 
pengawasan pemilihan pilkada serentak tahun 2020 penting mempertimbangkan aspek-aspek teknis dan yuridis dari regulasi COVID-194.

Berkaitan dengan pandemi COVID-19, Komisi Pemilihan Umum akhirnya mengeluarkan Surat Keputusan KPU Nomor: 179/PL.02-kpt/01/KPU/III/2020 tentang Penundaan Tahapan Pemilihan Gubernur dan Wakil Gubernur, Bupati dan Wakil Bupati, dan/atau Wali Kota dan Wakil Wali Kota tahun 2020 dalam Upaya Pencegahan Penyebaran Covid-19. Surat Keputusan KPU tersebut memuat aturan tentang penundaan beberapa tahapan Pilkada 2020. Keputusan KPU menyangkut hal tertundanya pelantikan dan masa kerja Panitia Pemungutan Suara (PPS), tertundanya proses verifikasi dukungan calon perseorangan, tertundanya pembentukan Petugas Pemutakhiran Data Pemilih (PPDP) dan pelaksanaan pencocokan dan penelitian (coklit), serta pemutakhiran dan penyusunan daftar pemilih.

Hal ini juga terjadi pada pemilihan bupati dan wakil bupati Kabupaten Pesisir Selatan. KPU Kabupaten Pesisir Selatan secara resmi menetapkan tiga pasangan calon bupati dan wakil bupati yaitu pasangan Hendrajoni- Hamdanus yang diusung ole partai Nasdem, PKS dan Demokrat, pasangan Rusma Yul Anwar-Rudi Hariyansyah yang diusung oleh parta Gerindra, PAN, Perindo, Berkarya dan PBB serta pasangan Dedi Rahmanto Putra-Arfinof Rajab yang diusung oleh parta Golkar, PDIP, PKB, PPP dan Hanura. sebagai peserta Pilkada 2020 yang dilaksanakan tanggal 9 Desember 2020. Penetapan itu setelah melalui proses pendaftaran dan pemeriksaan dokumen persyaratan yang diserahkan masing-masing kandidat. Dari hasil penelitian, seluruh persyaratan dinyatakan lengkap dan sesuai keabsahan. Pemenang pilkada Kabupaten Pesisir Selatan adalah pasangan Rusma Yul Anwar-Rudi Hariyansyah yang diusung oleh parta Gerindra, PAN, Perindo, Berkarya dan PBB dengam raihan suara 128.992 (56,9\%).

Namun hasil Pilkada serentak pemilihan Bupati dan Wakil Bupati Kabupaten Pesisir Selatan tahun 2020 menemui beberapa kendala. Hal ini terkait dengan gugatan salah satu pasangan calon yaitu pasangan calon nomor urut 1 (satu) yaitu Hendrajoni Dt. Bando Basau, S.H., M.H dan Hamdanus, S.Fils.I., M.Si kepada Mahkamah Konstitusi terhadap hasil perhitungan suara yang telah dituangkan dalam keputusan KPU Kabupaten Pesisir Selatan Nomor: 368/PL.02.1.Kpt/1301/KPU-Kab/XII/2020 tentang Penetapan Rekapitulasi Hasil Penghitungan Suara Pemilihan Bupati dan Wakil Bupati Pesisir Selatan Tahun 2020.

Gugatan yang diajukan pasangan nomor urut 1 (satu), terdapat selisih perolehan suara, disebabkan: (1) jumlah seluruh pengguna hak pilih $(\mathrm{B} 1+\mathrm{B} 2+\mathrm{B} 3)$ tidak boleh lebih besar dari jumlah seluruh pemilih di TPS jumlah pemilih $(A 1+A 2+A 3)$, (2) jumlah surat suara yang digunakan tidak boleh lebih besar dari surat suara yang diterima, (3) jumlah surat surat suara yang digunakan harus sama dengan jumlah pengguna hak pilih dan(4) jumlah seluruh suara sah dan tidak sah (VC) harus sama dengan jumlah surat suara yang digunakan dan jumlah pengguna hak pilih.

\footnotetext{
${ }^{4}$ Jhon Retei, dkk, Fenomena Pengawasan Pemilihan Kepala Derah di Kalimantan Tengah Masa Pandemi Covid 19, Jurnal Politik Pemerintahan Dharma Praja, Volume. 13, No. 1, Tahun 2019, hlm. 9
} 
Berdasarkan uraian diatas perumusan masalah dalam artikel ini "Bagaimanakah Implikasi Pemilihan Kepala Daerah Serentak sebagai Perwujudan Demokrasi pada Masa Pandemi Covid 19 di Kabupaten Pesisir Selatan”.

\section{METODE PENELITIAN}

Penelitian artikel ini menerapkan jenis penelitian berupa penelitian hukum yuridis normatif (doctrinal research). Penelitian hukum yuridis normatif (doctrinal research) dilakukan dengan mempelajari dan menelaah suatu topik permasalahan dengan data sekunder untuk menemukan jawabannya. Data sekunder adalah data yang diperoleh secara tidak langsung dari bahan kepustakaan atau literatur yang ada hubungannya dengan objek penelitian. ${ }^{5}$ Data sekunder yang diperoleh dari bahan pustaka, mencakup badan hukum primer, sekunder dan tersier untuk menganalisis permasalahan hukum dalam tulisan ini. Penelitian hukum yuridis normatif (doctrinal research) melibatkan penelitian terhadap asas-asas hukum, sistematika hukum, taraf sinkronisasi hukum, perbandingan hukum dan sejarah hukum. ${ }^{6}$

Pengumpulan data untuk pemecahan masalah dilakukan dengan penelitian kepustakaan (library research), yang lalu dianalisis secara kualitatif. Analisis kualitatif yakni analisis data yang bersumber dari bahan hukum bertumpu pada peraturan perundang-undangan, doktrin, prinsip hukum, pendapat pakar, konsep, teori dan pandangan peneliti sendiri. Terakhir, menyusun bahan-bahan yang terkumpul menjadi data hukum yang dapat menjawab permasalahan yang telah diuraikan sebelumnya. Penelitian ini menggunakan pendekatan Undang-Undang (statue approach) dan pendekatan perbandingan (comparative approach). Metode analisis penelitian ini dilakukan agar penulis dapat mencapai suatu konklusi yang benar.

\section{HASIL DAN PEMBAHASAN}

Implikasi pelaksanaan pemilihan kepala daerah serentak sebagai perwujudan demokrasi pada masa pandemi Covid 19 di Kabupaten Pesisir Selatan

\section{Partisipasi Masyarakat dalam Mengikuti Pilkada pada masa pandemi Covid 19 di Kabupaten Pesisir Selatan}

Pilkada di kabupaten Pesisir Selatan dilaksanakan dengan mematuhi protokol kesehatan dalam rangka mencegah penyebaran Covid-19 semakin luas. Pelaksanaan pilkada difokuskan dalam rangka meningkatkan rasa patuh terhadap protokol kesehatan pelaksanaan Pilkada di masa pandemi Covid-19. Namun dalam pelaksanaan pilkada di Kabupaten Pesisir Selatan, adanya protokol kesehatan tidak berpengaruh pada partisipasi politik masyarakat. Masyarakat banyak yang menjalankan kewajibannya sebagai warga negara dengan menyalurkan hak pilihnya walaupun dengan protocol Kesehatan yang ketat.

Partisipasi pemilih pada Pilkada Kabupaten Pesisir Selatan tertinggi di Kecamatan IV Jurai yaitu 75,56\% dan terendah Kecamatan Pancung Soal yaitu 60,62\%. Tingginya angka

\footnotetext{
${ }^{5}$ Ishaq, I. (2017). Metode Penelitian Hukum dan Penulisan Skripsi, Tesis, serta Disertasi. Bandung: Alfabeta., hlm. 67.

6 Tan, D. (2021). Metode Penelitian Hukum: Mengupas Dan Mengulas Metodologi Dalam Menyelenggarakan Penelitian Hukum. Nusantara: Jurnal Ilmu Pengetahuan Sosial, 8(8), 2463-2478. hlm. 2468.
} 
partisipasi pemilih di Kecamatan IV Jurai dapat dimaklumi, karena kecamatan ini adalah pusat pemerintah Kabupaten Pesisir Selatan. Tingginya motivasi dalam memilih juga salah satunya disebabkan oleh informasi yang diterima oleh masyarakat tentang Pilkada Tahun 2020 termasuk lengkap, karena dekat dengan pusat informasi tentang pemilu tersebut.

\section{Sengketa Hasil Peroleh Suara Pilkada di Kabupaten Pesisir Selatan}

Sengketa yang dilakukan oleh salah satu pasangan pada Pilkada Kabupaten Pesisir Selatan dibantah oleh KPU. Menurut bukti yang dimiliki oleh KPU Kabupaten Pesisir Selatan, hampir di seluruh TPS di 182 Nagari yang berada di 15 kecamatan di Pesisir Selatan pendukung Pasangan Calon Hendrajoni - Hamdanus yang secara aktif melaporkan bahwa mereka tidak mendapatkan undangan untuk datang ke TPS (Formulir C6). Mereka tidak berani datang ke TPS karena adanya larangan untuk berkumpul sehingga mereka khawatir terkena pandemi virusCovid-19 akibat berkumpul di TPS. Adapun sebagian bukti yang dapat disampaikan pada permohonan ini adalah sebagai berikut; Pendukung Pasangan Calon Hendrajoni - Hamdanus yang melaporkan tidak mendapatkan undangan untuk datang memilih ke TPS yaitu sejumlah 342 orang, yaitu: Pancung Soal, 38 orang, IV Jurai, 17 orang, Koto XI Tarusan, 4 orang, Lengayang, 147 orang, Sutera, 27 orang, Linggo Sari Baganti, 74 orang, Bayang, 32 orang, Ranah Pesisir, 3 orang.

Fakta hasil pemeriksa kesehatan pasangan calon Bupati dan Wakil Bupati Kabupaten Pesisir Selatan di tetapkan oleh Ikatan Dokter Indonesia Wilayah Sumatera Barat bukan diterbitkan oleh Keputusan Rumah Sakit Pemerintah yang berwenang, oleh karenannya penerbitan Surat Keputusan Tim Pemeriksa Kesehatan yang dikeluarkan oleh IDI cacat hukum, karena IDI hanyalah organisasi profesi kedokteran Indonesia.

Kendala dalam pelaksanaan pemilihan kepala daerah serentak sebagai perwujudan demokrasi pada masa pandemi Covid 19 di Kabupaten Pesisir Selatan

\section{Netralitas ASN dalam Pilkada pada masa pandemi Covid 19 di Kabupaten Pesisir Selatan}

Netralitas ASN pada pelaksanaan Pilkada serentak pada masa pandemi Covid 19 di Kabupaten Pesisir Selatan, diantaranya:Pada tahapan Pencalonan Penyelenggaran Pemilihan Bupati dan Wakil Bupati Kabupaten Pesisir Selatan, Bawaslu Kabupaten Pesisir Selatan ditemukan video ASN melakukan Penyampaian Visi-Misi sebagai calon Bupati Kabupaten Pesisir Selatan di Partai Golkar, adanya ASN yang mendaftar sebagai calon Bupati Kabupaten Pesisir Selatan di Partai Golkar. Pada tahapan Kampanye Penyelenggaran Pemilihan Bupati dan Wakil Bupati Kabupaten Pesisir Selatan, ditemukan ASN melakukan pendampingan salah satu pasangan dengan cara mengajak dan mengerahkan masyarakat untuk mengantarkan calon Bupati Kabupaten Pesisir Selatan mendaftar ke KPU Kabupaten Pesisir Selatan. Pada tahapan distribusi logistik dan masa tenang Penyelenggaran PemilihanBupati dan Wakil Bupati Kabupaten Pesisir Selatan, Bawaslu Kabupaten Pesisir Selatan, didapatkan ASN yang memperlambat proses distribusi logistic. 


\section{Kondisi Geografis Daerah}

Kendala dalam pengelolaan logistik, yaitu letak geografis beberapa TPS yang agak sulit, seperti di Pulau Kapo-Kapo, Dilan Muaro Aie dan Dilan Pancuang Taba. Untuk mengantisipasi keterlambatan dan rusaknya logistik, dilakukan pengiriman lebih awal dan proteksi lebih dibanding logistik pada TPS lainnya. Logistik yang pengadaannya oleh KPU Provinsi Sumatera Barat sering kali terlambat tiba di KPU Kabupaten Pesisir Selatan sehinggapada saat sudah mendekati hari pemungutan suara masih ada beberapa logistik yang belum di terima, dan mengakibatkan terjadinya ketergesa-gesaan dalam menyortir dan memilah logistik untuk didistribusikan ke kecamatan karena berkejaran dengan waktu.

Kendala yang cukup besar dalam pelaksaan proses pemungutan dan penghitungan suara serta rekapitulasi penghitungan suara menggunakan Sirekap di kecamatan Bayang Utara, karena terdapat sebanyak 3 Nagari yang belum mendapatkan akses internet sama sekali disebabkan daerah jauh. KPPS di 3 Nagari tersebut terpaksa menempuh jarak yang cukup jauh guna mendapatkan akses internet untuk mengirimkan data TPS masing-masing ke server Sirekap. Dengan terkendalanya proses Sirekap mobile di 3 Nagari tersebut, tentu saja mengakibatkan rekapitulasi suara menggunakan Sirekap Web di Kecamatan menjadi tertunda.

\section{Perangkat Pendukung Pilkada}

Sesuai dengan peraturan KPU Nomor 5 Tahun 2020, rekapitulasi di Kecamatan dilakukan dari tanggal 10 Desember 2020 sampai dengan 14 Desember 2020. Proses rekapitulasi di tingkat kecamatan pada awalnya direncanakan akan dilakukan dengan menggunakan Sirekap Web PPK, namun hal ini urung dilakukan karena tidak maksimalnya pengoperasian Sirekap mobile di tingkat TPS. Oleh KPU Kabupaten Pesisir Selatan, PPK diminta melakukan proses rekapitulasi secara manual dengan menggunakan dokumen berformat ms. Excel namun dengan tetap melakukan proses foto formulir model C. Proses menggunakan Sirekap mobile sebagai perangkat Pilkada di Kabupaten Pesisir Selatan melelahkan karena harus mencari jadwal server yang stabil, KPU Kabupaten Pesisir Selatan harus menerima kenyataan bahwa proses Sirekap mobile tidak bisa diselesaikan oleh seluruh KPPS di Kabupaten Pesisir Selatan

\section{KESIMPULAN}

Implikasi pelaksanaan pemilihan kepala daerah serentak sebagai perwujudan demokrasi pada masa pandemi Covid 19 di Kabupaten Pesisir Selatan, yaitu meningkatnya partisipasi pemilih pada Pilkada tahun 2020 dibanding Pilkada Tahun 2015. Implikasi selanjutnya adalah munculnya sengketa terhadap hasil perolehan suara dalam Pilkada.

Kendala dalam pelaksanaan pemilihan kepala daerah serentak sebagai perwujudan demokrasi pada masa pandemi Covid 19 di Kabupaten Pesisir Selatan yaitu tidak netralnya Aparatur Sipil Negara dalam penyelenggaran Pilkada dengan melakukan pelanggaran pada beberapa tahapan pilkada, kendala kondisi geografis daerah serta kendala dalam perangkat yang digunakan untuk Pilkada 
Untuk itu ke depannya agar KPU Provinsi Sumatera Barat melakukan proses pengadaan lebih awal atau melimpahkan pengadaannya ke KPU Kabupaten Pesisir Selatan jika peraturan perundang-undangan memungkinkan. Pemerintah, memperhatikan kondisi pandemic Covid 19 sebelum melaksanakan Pilkada dengan mempertimbangan kesehatan masyarakat serta kondisi politik di daerah bersangkutan.

\section{DAFTAR PUSTAKA}

Abu Nashr Muhammad Al-Iman, Membongkar Dosa-dosa Pemilu, Prisma Media, Jakarta, 2004

Azumardi Azra, Demokrasi, Hak Asasi Manusia, dan Masyarakat Madani, Prenada Media, Jakarta, 2005

Gregorius Sahdan, "Pilkada dan Problem Demokrasi Lokal", dalam Gregorius Sahdan (et al), Politik Pilkada: Tantangan Merawat Demokrasi, (Yogyakarta: The Indonesian Power forDemocracy (IPD), 2008

Munir Fuady, Konsep Negara Demokrasi, Revita Aditama, Bandung, 2010

Ramlan Surbakti dkk, Seri Demokrasi Elektoral Buku 16 Penanganan Sengketa Pemilu, Kemitraan Bagi Pembaruan Tata Pemerintahan, 2011

Samuel P. Huntington, Gelombang Demokratisasi Ketiga, Pustaka Utama Grafiti, Jakarta, 1997

Suharizal, Pemilukada, Dinamika, dan Konsep Mendatang, Raja Grafindo Persada, Jakarta, 2011

Zakaria Bangun, Demokrasi dan Kehidupan Demokrasi di Indonesia, Bina Media Perintis, Medan, 2008

Alim Bathoro, Perangkap Dinasti Politik dalam Konsolidasi Demokrasi, Jurnal FISIP UMRAH, Volume. 2, No. 2, Tahun 2011

Firdaus, Penyelesaian Sengketa Pemilu sebagai Upaya Memulihkan Kepercayaan dan Memperkuat Legitimasi Pemerintahan Demokrasi, Fiat Justisia Jurnal Ilmu Hukum Vol.8 No.2 Tahun 2014, Fakultas Hukum Universitas Lampung

Herma Yanti, Gagasan Constitutional Complaint Sebagai kewenangan Baru Mahkamah Konstitusi dalam Perlindungan Hak Konstitusional, Jurnal Wajah Hukum, Volume 2 Nomor 2 (Oktober 2018)

Jhon Retei, dkk, Fenomena Pengawasan Pemilihan Kepala Derah di Kalimantan Tengah Masa Pandemi Covid 19, Jurnal Politik Pemerintahan Dharma Praja, Volume. 13, No. 1, Tahun 2019

Utomo, W. W.. Kebijakan Penyelenggaran Pilkada (Menghadapi Pilkada 2020 Ditengah Covid 19 Dan New Normal). Jurnal Al-Harakah, 3(01), 2020 